\title{
A Systematic Review on Drug Resistant Urinary Tract Infection Among Pregnant Women in Developing Countries in Africa and Asia; 2005-2016
}

This article was published in the following Dove Press journal:

Infection and Drug Resistance

\section{Melaku Ashagrie Belete (iD) Muthupandian Saravanan (iD) ${ }^{2}$ \\ 'Department of Medical Laboratory Science, College of Medicine and Health Science, Wollo University, Dessie II45, Ethiopia; ${ }^{2}$ Department of Medical Microbiology and Immunology, Division of Biomedical Sciences, School of Medicine, College of Health Sciences, Mekelle University, Mekelle, I87I, Ethiopia}

Background: Urinary tract infection is one of the most common health problems during pregnancy. It is most commonly reported among pregnant women and is a known reason of morbidity during pregnancy worldwide, predominantly in developing countries. The etiological agents include Escherichia coli, Klebsiella species, Staphylococcus aureus, coagulase negative Staphylococci, Proteus mirabilis, Enterococcus species, Pseudomonas aeruginosa, Enterobacter species, non-hemolytic streptococci, Citrobacter species and others. Different risk factors expose pregnant women to urinary tract infection. Drug resistance by uropathogenic bacteria is a current problem of the world. This study was aimed at reviewing the prevalence of bacterial uropathogens and their antimicrobial resistance patterns among pregnant women in developing countries in Asia and Africa, during the past decade.

Methods: A systematic literature search was accomplished to identify published studies between January 2005 and November 2016. The literature search strategy in this paper included searching PubMed, PMC, Science Direct, Springer open, Google scholar and BioMed Central databases.

Results: The overall prevalence of UTI among pregnant women was $13.5 \%$. Both Grampositive and Gram-negative bacteria were isolated from all eligible studies. Gram-negative bacteria (83.7\%) accounted for majority of infections while Gram positives accounted for $15.9 \%$. Among the isolated bacteria, Escherichia coli was the most predominant uropathogen; it was shown to be present in all 26 eligible studies that were included in this review. Four studies from Africa and four from Asia were reviewed for antimicrobial resistance patterns of uropathogenic bacteria. In most of the regions, almost all the bacterial uropathogens had high resistance to ampicillin $(67.2 \%)$ whereas all the strains showed relative sensitivity to ciprofloxacin $(71.2 \%)$, nitrofurantoin (65\%) and ceftriaxone (74.1\%).

Conclusion: The prevalence of UTI in the selected regions of the two continents is different. A significant prevalence of UTI among pregnant women is mainly observed in Africa and Asia. Uropathogenic bacteria showed resistance to antimicrobial drugs that are regularly used in developing countries. This may show the need to incorporate culture and drug susceptibility tests into the routine antenatal care for pregnant women and drug resistance should be monitored.

Keywords: urinary tract infection, bacterial profile, pregnant women, antimicrobial resistance, developing countries

\section{Background}

Urinary Tract Infection (UTI) is the invasion and subsequent multiplication of microorganisms anywhere in the urinary tract. ${ }^{1}$ The urinary tract consists of the

Muthupandian Saravanan

Tel +25I 924381557

Email saravanan.muthupandian@mu.edu.et 
organs involved in collecting and storing urine and releases it from the body including, urethra, urinary bladder, ureters, kidneys and other auxiliary parts. Anatomically, UTI is categorized into upper UTI involving the kidney, pelvis and ureter and lower UTI comprising the bladder and urethra. ${ }^{1}$ Urinary tract infection is ascending in nature, with infecting organisms moving from the perineal region and vagina in females. Females are three times more likely to get UTI than males, due to women's shorter urethra which opens nearer to the anus, nature of sexual activity, pregnancy, easy contamination of the urinary tract with faecal flora and hormonal changes that occur very quickly. $^{2}$ The ratio of urinary tract infection between female and males stands at 8:1. Worldwide, about onethird of adult women have experienced symptomatic cystitis disease at least once in their life and one half have experienced recurring UTI as a result of previous UTI infection. It is commonly caused by bacteria from digestive tract which are capable of ascending to the urethral opening and cause infection. ${ }^{3}$ E. coli is the most common etiologic agent of UTI and it causes $68-77 \%$ of recurrent UTI infections. ${ }^{3}$

Urinary tract infection is one of the most common infectious diseases causing over 150 million cases per year worldwide costing the world economy over 6 billion US dollars in treatment and is affecting all age groups. ${ }^{4}$ Urinary tract infections are common in pregnant women and pose a great therapeutic challenge, as the risk of serious complications is very high to both the mother and her child. Pregnant women are more susceptible to developing UTI and according to WHO one in five women will encounter the UTI. ${ }^{5}$ Also, pregnant women have 4 times higher rate of developing UTI while compared with non-pregnant women. ${ }^{5}$

UTI is among the most commonly studied health problems in pregnancy; it has shown a prevalence ranging from 3 to $35 \%$ in different parts of the world in which increased prevalence is predominantly seen in developing countries including Africa and Asia. ${ }^{6}$ The risk of developing UTI usually commences at $6^{\text {th }}$ week and then will reach its peak during the $22-24^{\text {th }}$ week of pregnancy as a result of various causes including increased bladder volume, urethral dilatation and decreased urethral tone which results in high urinary stasis and vesicoureteral reflux. ${ }^{7}$ In addition, $70 \%$ of pregnant women develop glycosuria during pregnancy; these factors collectively facilitate urinary bacterial growth. ${ }^{7}$

Untreated UTI in pregnancy either symptomatic or asymptomatic is associated with a $50 \%$ increase in the risk of maternal complications of pregnancy including pyelonephritis, hypertension, preeclampsia, anaemia, endometritis, renal scarring, renal failure and raise extent of preterm labour and delivery which consequently cause prematurity and low birth weight with high perinatal morbidity and mortality. ${ }^{8,9}$ Furthermore, pregnant patients with untreated UTI may suffer from maternal-fetal complications, including septicemia, intra-amniotic infection, premature rupture of membranes, intrauterine growth restriction and perinatal death. ${ }^{6}$ Adequate and early treatment reduces the incidence of these complications. ${ }^{10}$

There is growing concern regarding antimicrobial resistance worldwide among causative agents of UTI in pregnant women. ${ }^{11}$ A rise in multidrug resistance to UTI is mainly attributed to an extensive unrestrained antibiotics usage habit in developing countries mainly due to the habitual trend of empirical antimicrobial treatment which is commonly started without obtaining the laboratory results of urine culture. Such practice results in the emergence of drug resistance and may lead to the spread of antimicrobial-resistant bacterial strains. As a result, antimicrobial resistance is one of the major causes of treatment failure for UTI. ${ }^{12}$

Different risk factors expose pregnant women to UTI including increasing parity status, increasing age, frequent sexual intercourse, diabetes, sickle cell disease and previous history of UTI. Others include gestational age, level of education, previous history of catheterization, poor personal hygiene, use of contraceptive and previous use of third-generation cephalosporins. ${ }^{13,14}$ Most importantly UTI in pregnancy is mainly related to poor hygiene and low socio-economic status of developing countries. ${ }^{13}$ There are several studies conducted by numerous researchers regarding the bacterial profile and antimicrobial susceptibility patterns of UTI in developing countries; hence, the aim of this study was to look at the global burden of UTI in low-income countries and to understand the antimicrobial resistance patterns and associated predisposing risk factors of bacterial uropathogens in pregnant women during the past decade (2005-2016).

\section{Methods}

\section{Search Strategy and Selection Criteria}

A systematic literature search was implemented to get published studies between January 2005 and November 2016. The literature search strategy in this paper included searching PubMed, PMC, Science Direct, Springer open, Google scholar and BioMed Central databases. 
Initial screening of all published studies was performed for eligibility based on the title relevancy. Then screening of full manuscript was done based on inclusion and exclusion criteria. Keywords used for the search of publications from the search engines include, prevalence, isolation, profile, epidemiology, burden, magnitude, distribution, risk factors, multidrug resistance, and antimicrobial resistance patterns of urinary tract infection among pregnant women. Each term was searched separately with the text string "Asia" and "Africa" and then with the name of all the specific countries in Asia and Africa regions. The WHO infectious diseases websites were also reviewed for relevant publications. Lastly, the bibliographies of each article were carefully reviewed and relevant articles were also retrieved. Studies conducted before 2005 and studies that only reported the overall prevalence of urinary tract infection without stating information on bacterial profile were excluded.

\section{Data Extraction}

Name of first author, publication year, country, setting, sample size, sample source, prevalence, bacterial profile and multidrug resistant pattern of UTI were extracted from the eligible studies. Amoxicillin, ampicillin, ciprofloxacin, nalidixic acid, trimethoprim-sulfamethoxazole, gentamicin, norfloxacin, nitrofurantoin and ceftriaxone resistance patterns of UTI causing bacteria were extracted from the respective eligible studies.

Studies were included in the review if they fulfilled the following criteria:

- Isolation and identification of UTI-causing bacterial uropathogens from urine specimen need to be based upon standard bacteriological methods and antimicrobial susceptibility testing need to be following Clinical Standards Laboratory Institute (CSLI) guidelines using disc diffusion methods.

- Full-text articles studied in Asia and Africa; and published in English any place in the world were included.

\section{Results}

One hundred sixty-eight articles were retrieved during the search process; out of which, 110 were excluded based on the abstract and relevance to our selected topic. The full text of the 58 remaining articles was further evaluated, but 32 of them were excluded as they did not fulfill the inclusion criteria. Finally, a total of 26 studies, 11 from Asia and 15 from African countries met the criteria and were included in this review.

Almost all of the reviewed studies were hospital-based studies; only a few studies were conducted in health center and clinics. All of the study participants were pregnant women without any age boundary. From all the eligible studies, mid-stream urine sample was the source of specimen. A total of 24,248 urine specimens' data were collected from all the illegible studies. Among the eligible studies, Six (22\%) were published before 2010 while the rest twenty-one (78\%) were published from 2010 to 2016 (Table 1).

\section{Prevalence and Antimicrobial Resistance}

Out of 24,248 urine specimens' data, the overall prevalence of UTI among pregnant women was 3271 (13.5\%). Both Gram-positive and Gram-negative bacteria were isolated from all eligible studies. Gram-negative bacteria were mentioned majorly in most of the studies and constituted 79.9\% (2613) whereas Gram-positive bacteria accounted for 647 (19.8\%). Most studies agreed on the fact that more than half of the UTI is caused by Escherichia coli. ${ }^{15-17}$ Similarly, in this review, among the isolated bacteria, Escherichia coli was the most common uropathogen; it was noted as the major pathogen in all 26 eligible studies that are included in this review. Klebsiella species were the second most common bacteria isolated from Ethiopia, ${ }^{14,15,18}$ India, ${ }^{3,19,20} \mathrm{Nepal}^{21}$ Nigeria, ${ }^{22-24}$ Ghana, ${ }^{25}$ Iran, ${ }^{26}$ Sudan, ${ }^{27}$ Cameroon, ${ }^{28}$ Yemen, ${ }^{29}$ South Africa, ${ }^{30}$ Uganda, ${ }^{31}$ Saudi Arabia, ${ }^{32}$ Tanzania, ${ }^{33,34}$ Bangladesh $^{35}$ (Table 1).

Escherichia coli was the number one Gram negative bacterial pathogen and found in all eligible studies from all countries (Figure 1). Staphylococcus aureus was the number one Gram positive pathogen predominately isolated from Ethiopia, ${ }^{14,15,17,18}$ Sri Lanka, ${ }^{36}$ Ghana, ${ }^{25}$ India, ${ }^{3,19}$ Nepal, ${ }^{21}$ Nigeria, ${ }^{22-24}$ Sudan, ${ }^{27}$ Yemen, ${ }^{29}$ Uganda, ${ }^{31}$ Saudi Arabia, ${ }^{32}$ Tanzania, ${ }^{33}$ Bangladesh, ${ }^{35}$ Pakistan ${ }^{37}$ and Iran. ${ }^{38}$ Whereas Proteus mirabilis was isolated from Ethiopia, ${ }^{14,15,18}$ Ghana, ${ }^{39}$ India,,${ }^{3,19,20}$ Nepal, ${ }^{21}$ Nigeria, ${ }^{22-24}$ Yemen, ${ }^{29}$ South Africa, ${ }^{30}$ Saudi Arabia, ${ }^{32}$ Tanzania ${ }^{33}$ and Bangladesh. ${ }^{35}$ On the other hand, Enterococci bacteria were isolated from Ghana, ${ }^{25,39}$ India, ${ }^{3,19,21}$ Nigeria, ${ }^{24}$ South Africa, ${ }^{30}$ Uganda, ${ }^{31}$ Tanzania ${ }^{33}$ and Ethiopia. ${ }^{18}$ Pseudomonas aeruginosa was also reported majorly from India, ${ }^{3,19,20} \mathrm{Nepal}^{21}$ Ethiopia, ${ }^{15,18}$ Nigeria, ${ }^{23,24}$ Sudan, ${ }^{27}$ Cameroon, ${ }^{28}$ Uganda $^{31}$ and Tanzania. ${ }^{34}$ Similarly, Enterobacter uropathogens were 


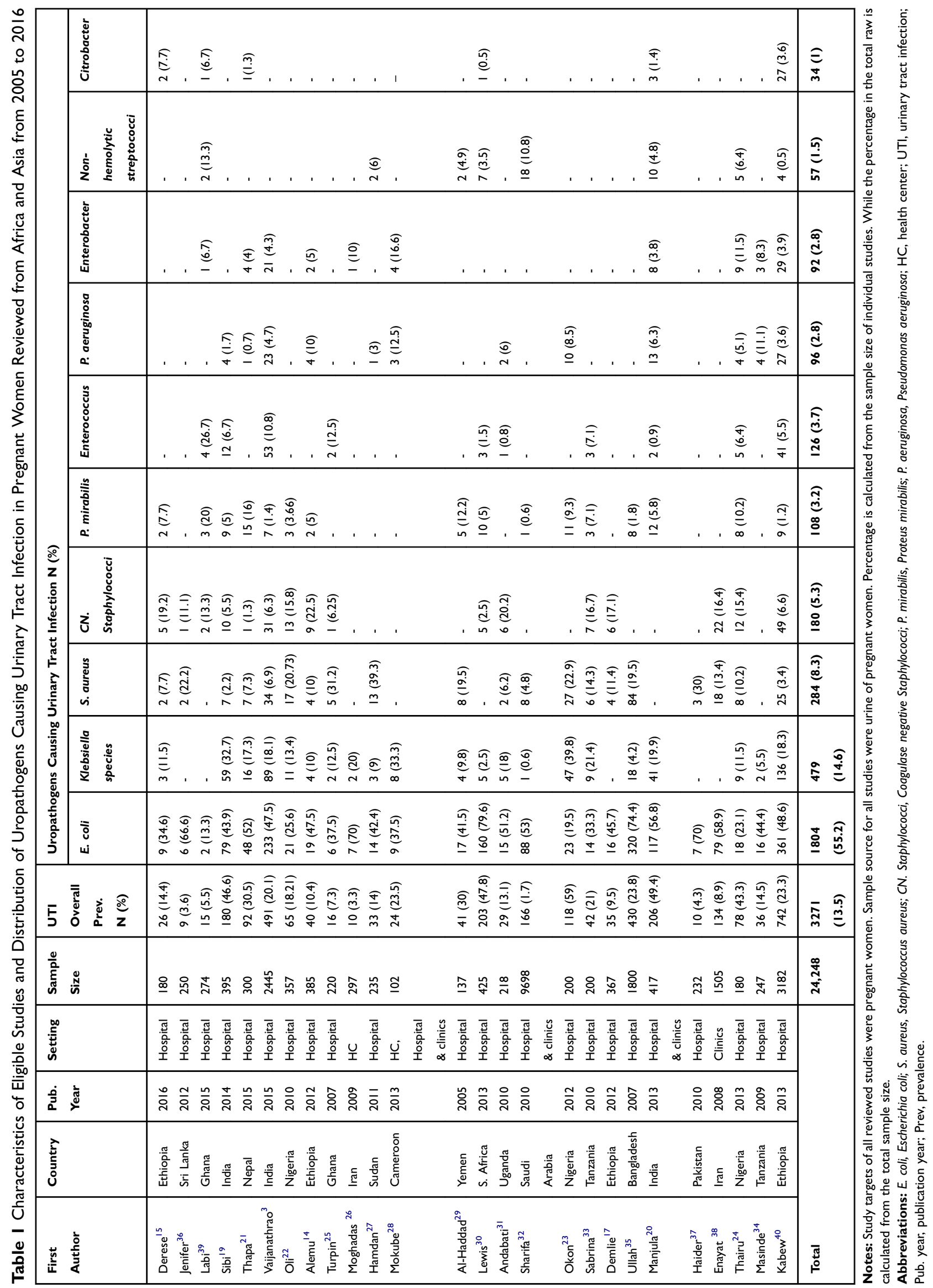




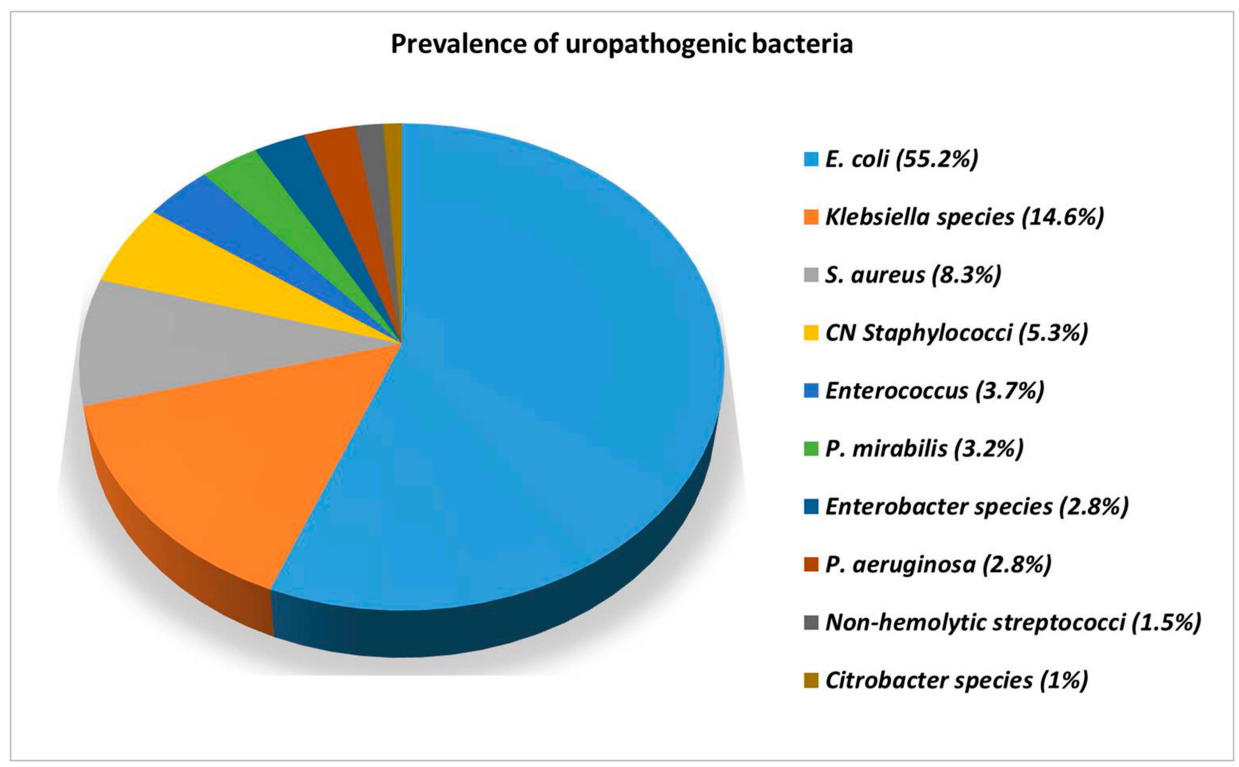

Figure I Frequency of uropathogenic bacteria among pregnant women in developing countries in Africa and Asia from 2005 to 2016.

isolated from Ghana, ${ }^{39}$ Nepal, $^{21}$ Ethiopia, ${ }^{14,18}$ Iran, ${ }^{26}$ Tanzania, ${ }^{34}$ Cameroon, ${ }^{28}$ India ${ }^{3,20}$ and Nigeria ${ }^{24}$ (Table 1).

Likewise, non-hemolytic Streptococci uropathogens were predominantly reported from Ghana, ${ }^{39}$ Sudan, ${ }^{27}$ Yemen, ${ }^{29}$ South Africa, ${ }^{30}$ Saudi Arabia, ${ }^{32}$ Ethiopia, ${ }^{18}$ Nigeria $^{24}$ and India. ${ }^{20}$ In addition, Citrobacter uropathogens were mainly reported from studies conducted in Ethiopia, ${ }^{15,18}$ India, $^{20}$ South Africa, ${ }^{30} \mathrm{Nepal}^{21}$ and Ghana $^{39}$ (Table 1).

The country wise overall prevalence of UTI among pregnant women showed South Africa (47.8\%), Nigeria (35.4\%), Nepal (30.5\%), Yemen (30.5\%), Bangladesh (23.8\%), India (23.6\%), Cameroon (23.5\%), Ethiopia (20.5\%), Tanzania (17\%), Brazil (15.6\%), Sudan (14\%), Uganda (13.1\%), Iran (8.9\%), Ghana (6.2\%), Pakistan (4.3\%), Sri Lanka (3.6\%), Iran (3.3\%) and Saudi Arabia (1.7\%).

Eight studies were eligible for antimicrobial resistance testing of uropathogenic bacteria. These are four from Africa (Table 3) and four from Asia (Table 2). In most of the regions, almost all the bacterial uropathogens had high resistance to ampicillin $(67.2 \%)$. Whereas all the strains showed relative sensitivity to ciprofloxacin (71.2\%), nitrofurantoin (65\%) and ceftriaxone (74.1\%). In most of the studies observed in Asia (Table 2) and Africa (Table 3), uropathogenic bacteria had resistance to Ampicillin and trimethoprim-sulfamethoxazole and most were sensitive to ciprofloxacin and nalidixic acid.

\section{Risk Factors}

Even though UTI is mainly considered as a result of bacterial infection, there are also numerous other predisposing factors that signify the infection. Physiological and hormonal changes that occur in the course of pregnancy, routes of infection as a result of reproductive physiology of females and urinary instrumentation are among the major factors predisposing pregnant women to acquire UTI (Figure 2). Pregnancy is a critical period and boosts the occurrence of UTI due to the following risk factors. The reviewed studies have identified different factors that play a vital role in predisposing to UTI during the course of pregnancy (Table 4). The previous history of UTI could be one of the risk factors for acquiring UTI during pregnancy. Most of the reviewed studies have reported that past UTI history has been significantly associated with UTI during the time of pregnancy. ${ }^{15,14,21,24,37}$ Moreover, due to the fact that all the reviewed articles were from developing countries, UTI showed a significant association with low socioeconomic status. ${ }^{15,34,37}$

In half of the eligible studies, the educational level of the study subjects has been found to have significant association with the development of UTI during pregnancy $^{15,21-23,37}$ implying that study participants having low educational level were prone to UTI during pregnancy mainly due to hygienic factors and inadequate awareness regarding other prominent risk factors of UTI; 
Table 2 Review on Antimicrobial Resistance Patterns of Uropathogens Causing UTI Among Pregnant Women in Developing Countries Conducted in Asia from 2005 to 2016

\begin{tabular}{|c|c|c|c|c|c|c|c|c|c|c|}
\hline \multirow[t]{2}{*}{ Author } & \multirow[t]{2}{*}{ Uropathogens } & \multicolumn{9}{|c|}{ Resistance Patterns, N (\%) } \\
\hline & & AMP & CIP & NA & SXT & GM & NOR & $\mathbf{F}$ & AMO & CRO \\
\hline $\operatorname{Sibi}^{19}$ & $\begin{array}{l}\text { E.coli } \\
\text { S. aureus } \\
\text { CN Staphylococci } \\
\text { Klebsiellaspp. } \\
\text { P. aeruginosa } \\
\text { P. mirabilis } \\
\text { Enterococcus }\end{array}$ & $\begin{array}{l}N / D \\
N / D \\
N / D \\
N / D \\
N / D \\
N / D \\
N / D\end{array}$ & $\begin{array}{l}18(22.8) \\
3(48) \\
4(40) \\
24(35.5) \\
0(0) \\
1(10.1) \\
4(33.3)\end{array}$ & $\begin{array}{l}4 \mid(5 I .9) \\
2(25) \\
2(20) \\
9(33) \\
1(33.3) \\
0(0) \\
0(0)\end{array}$ & $\begin{array}{l}13(16.5) \\
2(25) \\
1(10) \\
17(25) \\
0(0) \\
3(33.3) \\
2(16.7)\end{array}$ & $\begin{array}{l}69(87.4) \\
3(50) \\
5(50) \\
29(42) \\
1(33.4) \\
6(66.7) \\
8(66.7)\end{array}$ & $\begin{array}{l}34(43.1) \\
5(75) \\
6(60) \\
16(57) \\
1(33.3) \\
3(33.3) \\
3(25)\end{array}$ & $\begin{array}{l}N / D \\
N / D \\
N / D \\
N / D \\
N / D \\
N / D \\
N / D\end{array}$ & $\begin{array}{l}75(94.9) \\
3(50) \\
3(30) \\
47(68) \\
2(50) \\
2(22.8) \\
3(25)\end{array}$ & $\begin{array}{l}32(40.5) \\
7(100) \\
4(40) \\
40(58) \\
I(33.3) \\
I(12) \\
5(42)\end{array}$ \\
\hline Thapa ${ }^{21}$ & $\begin{array}{l}\text { E. coli } \\
\text { Klebsiellaspp. } \\
\text { P. aeruginosa } \\
\text { P. mirabilis } \\
\text { Enterococcus } \\
\text { Citrobacter }\end{array}$ & $\begin{array}{l}44(56.4) \\
20(76.4) \\
0(0) \\
13(54.2) \\
4(66.7) \\
I(50)\end{array}$ & $\begin{array}{l}32(4 \mathrm{I}) \\
10(38.5) \\
0(0) \\
7(29.2) \\
3(50) \\
1(50)\end{array}$ & $\begin{array}{l}N / D \\
N / D \\
N / D \\
N / D \\
N / D \\
N / D\end{array}$ & $\begin{array}{l}32(41) \\
10(38.5) \\
1(100) \\
12(50) \\
4(66.7) \\
2(100)\end{array}$ & $\begin{array}{l}6(7.7) \\
3(11.5) \\
0(0) \\
3(12.5) \\
0(0) \\
0(0)\end{array}$ & $\begin{array}{l}46(58.9) \\
2(7.69) \\
I(100) \\
I(4.2) \\
3(50) \\
I(50)\end{array}$ & $\begin{array}{l}8(10.3) \\
7(26.9) \\
0(0) \\
4(16.7) \\
0(0) \\
1(50)\end{array}$ & $\begin{array}{l}N / D \\
N / D \\
N / D \\
N / D \\
N / D \\
N / D\end{array}$ & $\begin{array}{l}N / D \\
N / D \\
N / D \\
N / D \\
N / D \\
N / D\end{array}$ \\
\hline Ullah ${ }^{35}$ & $\begin{array}{l}\text { E. coli } \\
\text { CN Staphylococci } \\
\text { Klebsiellaspp. } \\
\text { P. mirabilis }\end{array}$ & $\begin{array}{l}N / D \\
N / D \\
N / D \\
N / D\end{array}$ & $\begin{array}{l}8(2.5) \\
6(7.1) \\
0(0) \\
0(0)\end{array}$ & $\begin{array}{l}186(58.1) \\
40(47.6) \\
6(33.3) \\
2(25)\end{array}$ & $\begin{array}{l}222(69.4) \\
58(66.7) \\
16(88.9) \\
6(75)\end{array}$ & $\begin{array}{l}N / D \\
N / D \\
N / D \\
N / D\end{array}$ & $\begin{array}{l}N / D \\
N / D \\
N / D \\
N / D\end{array}$ & $\begin{array}{l}160(50) \\
36(42.4) \\
4(22.2) \\
2(25)\end{array}$ & $\begin{array}{l}170(53) \\
34(40.5) \\
10(55.6) \\
4(50)\end{array}$ & $\begin{array}{l}N / D \\
N / D \\
N / D \\
N / D\end{array}$ \\
\hline Enayat $^{38}$ & $\begin{array}{l}\text { E. coli } \\
\text { S. aureus } \\
\text { CN Staphylococci } \\
\text { Klebsiellaspp. } \\
\text { Enterobacter }\end{array}$ & $\begin{array}{l}77(97.5) \\
12(66.7) \\
14(63.6) \\
2(40) \\
6(60)\end{array}$ & $\begin{array}{l}10(92.7) \\
12(66.7) \\
8(38.4) \\
1(20) \\
2(20)\end{array}$ & $\begin{array}{l}64(8 I . I) \\
\text { N/D } \\
2(27.3) \\
4(80) \\
I(10)\end{array}$ & $\begin{array}{l}59(74.7) \\
14(77.7) \\
18(81.8) \\
4(80) \\
3(30)\end{array}$ & $\begin{array}{l}75(94.9) \\
N / D \\
N / D \\
2(40) \\
3(30)\end{array}$ & $\begin{array}{l}21(26.6) \\
3(16.6) \\
12(54.6) \\
N / D \\
6(60)\end{array}$ & $\begin{array}{l}56(70.9) \\
10(55.5) \\
12(54.6) \\
N / D \\
4(40)\end{array}$ & $\begin{array}{l}N / D \\
N / D \\
N / D \\
N / D \\
N / D\end{array}$ & $\begin{array}{l}N / D \\
N / D \\
N / D \\
N / D \\
N / D\end{array}$ \\
\hline
\end{tabular}

Notes: Resistance patterns for each studies were calculated as a percentage of individual bacterial isolates. All studies use Clinical and Laboratory Standards Institute (CLSI) guideline to depict the resistance patterns of each bacterial isolate.

Abbreviations: N/D, resistance pattern not determined; AMP, ampicillin; CIP, ciprofloxacin; NA, nalidixic acid; SXT, trimethoprim-sulfamethoxazole; GM, gentamicin; NOR, norfloxacin; F, nitrofurantoin; AMO, amoxicillin; CRO, ceftriaxone.

however, nearly half of the studies reported insignificant association. ${ }^{14,31,34,36,39}$ High sexual activity during pregnancy has also been found to be significantly associated with UTI in few studies conducted in Asia and Africa; ${ }^{19,37,39}$ moreover, it was also an established risk factor in the western world and it is significantly associated with UTI during pregnancy. ${ }^{6}$

Despite the fact that majority of the reviewed studies reported that parity did not show significant association with UTI in pregnancy, there were some studies conducted in Nepal, Nigeria, Brazil, India and Pakistan that showed a significant association ${ }^{20,21,23,37}$ inferring a boost in the number of childbirth would raise the occurrence of UTI during pregnancy. Unlike few studies, ${ }^{20,23-25}$ most of the reviewed studies revealed that gestational age was not significantly associated with bacteriuria.

Gravidity also played a vital role in predisposing to UTI. Data from most of the studies have indicated that gravidity is not significantly associated with UTI. However, two studies from Saudi Arabia $^{32}$ and Nigeria ${ }^{23}$ reported significant association between gravidity and UTI during pregnancy. History of catheterization is another risk factor for UTI in pregnancy; one of the studies from Ethiopia ${ }^{14}$ has shown a significant association stating that pregnant women who had repeated use of catheter would mediate bacterial inoculation into urogenital tract and might result in UTI during pregnancy.

Maternal age has also been shown as a risk factor for UTI during pregnancy. Nearly half of the reviewed studies have shown that maternal age is significantly associated with the development of UTI ${ }^{15,19,20,24,34}$ indicating that pregnant women with increased age group were more exposed to acquire UTI during pregnancy as aging is one of the predominant factors for heightened infections due to lowered immunity and diminished physiological activities.

Most commonly women with diabetes are more exposed to UTI than non-diabetic women. ${ }^{3,20,36}$ This is mainly due to the 
Table 3 Review on Antimicrobial Resistance Patterns of Uropathogens Causing UTI Among Pregnant Women in Developing Countries Conducted in Africa from 2005 to 2016

\begin{tabular}{|c|c|c|c|c|c|c|c|c|c|c|}
\hline \multirow[t]{2}{*}{ Author } & \multirow[t]{2}{*}{ Uropathogens } & \multicolumn{9}{|c|}{ Resistance Patterns, N (\%) } \\
\hline & & AMP & CIP & NA & $\mathbf{S X T}$ & GM & NOR & $\mathbf{F}$ & AMO & CRO \\
\hline Derese $^{15}$ & $\begin{array}{l}\text { E. coli } \\
\text { S. aureus } \\
\text { Klebsiellaspp. } \\
\text { P. aeruginosa } \\
\text { P. mirabilis } \\
\text { Citrobacter } \\
\text { CN staphylococci }\end{array}$ & $\begin{array}{l}7(77.7) \\
2(100) \\
3(100) \\
4(100) \\
2(100) \\
1(100) \\
4(80)\end{array}$ & $\begin{array}{l}\text { I }(I I . I) \\
\text { I }(50) \\
\text { I }(33.3) \\
\text { I }(25) \\
0(0) \\
0(0) \\
2(40)\end{array}$ & $\begin{array}{l}4(44.5) \\
N / D \\
\text { I }(33.5) \\
3(75) \\
\text { I }(50) \\
\text { I }(100) \\
N / D\end{array}$ & $\begin{array}{l}\text { I }(1 \mathrm{I} .1) \\
\text { I }(50) \\
2(66.7) \\
4(100) \\
\text { I }(50) \\
0(0) \\
4(80)\end{array}$ & $\begin{array}{l}0(0) \\
0(0) \\
I(33.3) \\
2(50) \\
0(0) \\
0(0) \\
0(0)\end{array}$ & $\begin{array}{l}\text { N/D } \\
\text { N/D } \\
\text { N/D } \\
\text { N/D } \\
\text { N/D } \\
\text { N/D } \\
\text { N/D }\end{array}$ & $\begin{array}{l}4(44.4) \\
\text { I (50) } \\
3(100) \\
3(75) \\
\text { I }(50) \\
0(0) \\
I(20)\end{array}$ & $\begin{array}{l}7(77.7) \\
1(50) \\
3(100) \\
2(50) \\
2(100) \\
0(0) \\
4(80)\end{array}$ & $\begin{array}{l}0(0) \\
I(50) \\
0(0) \\
I(25) \\
0(0) \\
0(0) \\
I(20)\end{array}$ \\
\hline $\operatorname{Labi}^{39}$ & $\begin{array}{l}\text { E. coli } \\
\text { CN Staphylococcus } \\
\text { P. mirabilis } \\
\text { Enterococcus }\end{array}$ & $\begin{array}{l}2(100) \\
2(100) \\
3(100) \\
4(100)\end{array}$ & $\begin{array}{l}N / D \\
N / D \\
N / D \\
N / D\end{array}$ & $\begin{array}{l}2(100) \\
1(50) \\
3(100) \\
3(75)\end{array}$ & $\begin{array}{l}2(100) \\
2(100) \\
3(100) \\
4(100)\end{array}$ & $\begin{array}{l}2(100) \\
2(100) \\
2(66.6) \\
4(100)\end{array}$ & $\begin{array}{l}N / D \\
N / D \\
N / D \\
N / D\end{array}$ & $\begin{array}{l}0(0) \\
0(0) \\
0(0) \\
0(0)\end{array}$ & $\begin{array}{l}N / D \\
N / D \\
N / D \\
N / D\end{array}$ & $\begin{array}{l}N / D \\
N / D \\
N / D \\
N / D\end{array}$ \\
\hline $\mathrm{Oli}^{22}$ & $\begin{array}{l}\text { E. coli } \\
\text { S. aureus } \\
\text { CN. staphylococcus } \\
\text { Klebsiella spp. } \\
\text { P. mirabilis }\end{array}$ & $\begin{array}{l}16(76.2) \\
15(88.3) \\
8(61.5) \\
9(81.8) \\
2(76.7)\end{array}$ & $\begin{array}{l}N / D \\
N / D \\
N / D \\
N / D \\
N / D\end{array}$ & $\begin{array}{l}\text { I6 (76.7) } \\
\text { I4 (82.4) } \\
9(69.3) \\
6(54.5) \\
\text { I (33.3) }\end{array}$ & $\begin{array}{l}12(57.2) \\
12(70.6) \\
10(76.9) \\
7(63.6) \\
2(76.7)\end{array}$ & $\begin{array}{l}7(33.3) \\
10(58.8) \\
3(23.1) \\
5(45.5) \\
1(33.3)\end{array}$ & $\begin{array}{l}N / D \\
N / D \\
N / D \\
N / D \\
N / D\end{array}$ & $\begin{array}{l}10(47.6) \\
14(82.4) \\
9(69.3) \\
8(72.3) \\
1(33.3)\end{array}$ & $\begin{array}{l}\text { II }(52.4) \\
\text { II }(64.7) \\
6(46.2) \\
7(63.7) \\
\text { I (33.3) }\end{array}$ & $\begin{array}{l}3(14.3) \\
6(35.3) \\
0(0) \\
2(17.3) \\
0(0)\end{array}$ \\
\hline Thairu $^{24}$ & $\begin{array}{l}\text { E.coli } \\
\text { S. aureus } \\
\text { CN. staphylococcus } \\
\text { Klebsiellaspp. } \\
\text { P. aeruginosa } \\
\text { P. mirabilis } \\
\text { Streptococcus } \\
\text { Enterococcus } \\
\text { Enterobacter }\end{array}$ & $\begin{array}{l}\text { II (60) } \\
0(0) \\
\text { I (4) } \\
5(55) \\
2(56) \\
4(50) \\
4(81.5) \\
\text { I (22) } \\
6(70)\end{array}$ & $\begin{array}{l}N / D \\
N / D \\
N / D \\
N / D \\
N / D \\
N / D \\
N / D \\
N / D \\
N / D\end{array}$ & $\begin{array}{l}N / D \\
N / D \\
N / D \\
N / D \\
N / D \\
N / D \\
N / D \\
N / D \\
N / D\end{array}$ & $\begin{array}{l}9(52.5) \\
5(59) \\
8(67) \\
2(22) \\
4(100) \\
7(90) \\
5(89.2) \\
3(68) \\
4(41.3)\end{array}$ & $\begin{array}{l}6(3 \mid .2) \\
4(44) \\
7(60) \\
4(49.2) \\
3(87.3) \\
4(53.7) \\
3(67.4) \\
2(45) \\
1(2.4)\end{array}$ & $\begin{array}{l}N / D \\
N / D \\
N / D \\
N / D \\
N / D \\
N / D \\
N / D \\
N / D \\
N / D\end{array}$ & $\begin{array}{l}4(20) \\
3(4 I .5) \\
7(55) \\
0(0) \\
3(68) \\
4(53.5) \\
3(53.1) \\
2(42.7) \\
5(50)\end{array}$ & $\begin{array}{l}I(8) \\
0(0) \\
0(0) \\
I(10) \\
I(33.4) \\
I(13.6) \\
0(0) \\
0(0) \\
2(20)\end{array}$ & $\begin{array}{ll}\text { I } & (5) \\
\text { I } & (3.2) \\
4 & (34) \\
3 & (33.2) \\
3 & (79.5) \\
5 & (55.4) \\
2 & (39.4) \\
\text { I }(12) \\
6(70)\end{array}$ \\
\hline
\end{tabular}

Notes: Resistance patterns for each study were calculated as a percentage of individual bacterial isolates. All studies use Clinical and Laboratory Standards Institute (CLSI) guideline to depict the resistance patterns of each bacterial isolate.

Abbreviations: N/D, resistance pattern not determined; AMP, ampicillin; CIP, ciprofloxacin; NA, nalidixic acid; SXT, trimethoprim-sulfamethoxazole; GM, gentamicin; NOR, norfloxacin; F, nitrofurantoin; AMO, amoxicillin; CRO, ceftriaxone.

rise in the use of various medical instruments such as a urinary catheter which heightens the probability of getting the infection. Besides, diabetes treatment exposes to the development of UTI. Moreover, higher content of glucose in urine, as well as the compromised immunity predispose to the UTI. However, none of the reviewed studies have shown significant association of UTI with Diabetic Mellitus and recent history of antibiotic treatment (Table 4).

\section{Discussion}

This review has addressed the prevalence of the uropathogenic bacteria, antimicrobial resistance patterns and risk factors of UTI among pregnant women conducted in 26 eligible studies reviewed from Asia and Africa.

Escherichia coli was the predominantly identified uropathogen $(100 \%)$ isolated from all the eligible studies reviewed from Asian and African countries. Klebsiella species was the second dominant uropathogen isolated from 82 and $87 \%$ of the eleven Asian and fifteen African countries, respectively. S. aureus was reviewed from 82 and $73 \%$ of the studies carried out in eleven Asia and fifteen African countries, respectively. Similarly, $C N$ Staphylococci was also reported in 45 and $73 \%$ of the studies conducted in eleven Asia and fifteen African countries, respectively. On the other hand, $P$. mirabilis was revealed from 64 and $60 \%$ of the studies carried out in eleven Asia and fifteen African countries, respectively. Enterococcus was reviewed from 27 and $47 \%$ of the studies conducted in eleven Asia and fifteen African countries, respectively. Whereas $P$. aeruginosa was reported from 36 and 53\% of the studies conducted in eleven Asia and fifteen African countries, respectively. Enterobacter uropathogens were revealed from 36 and $40 \%$ of the eleven 


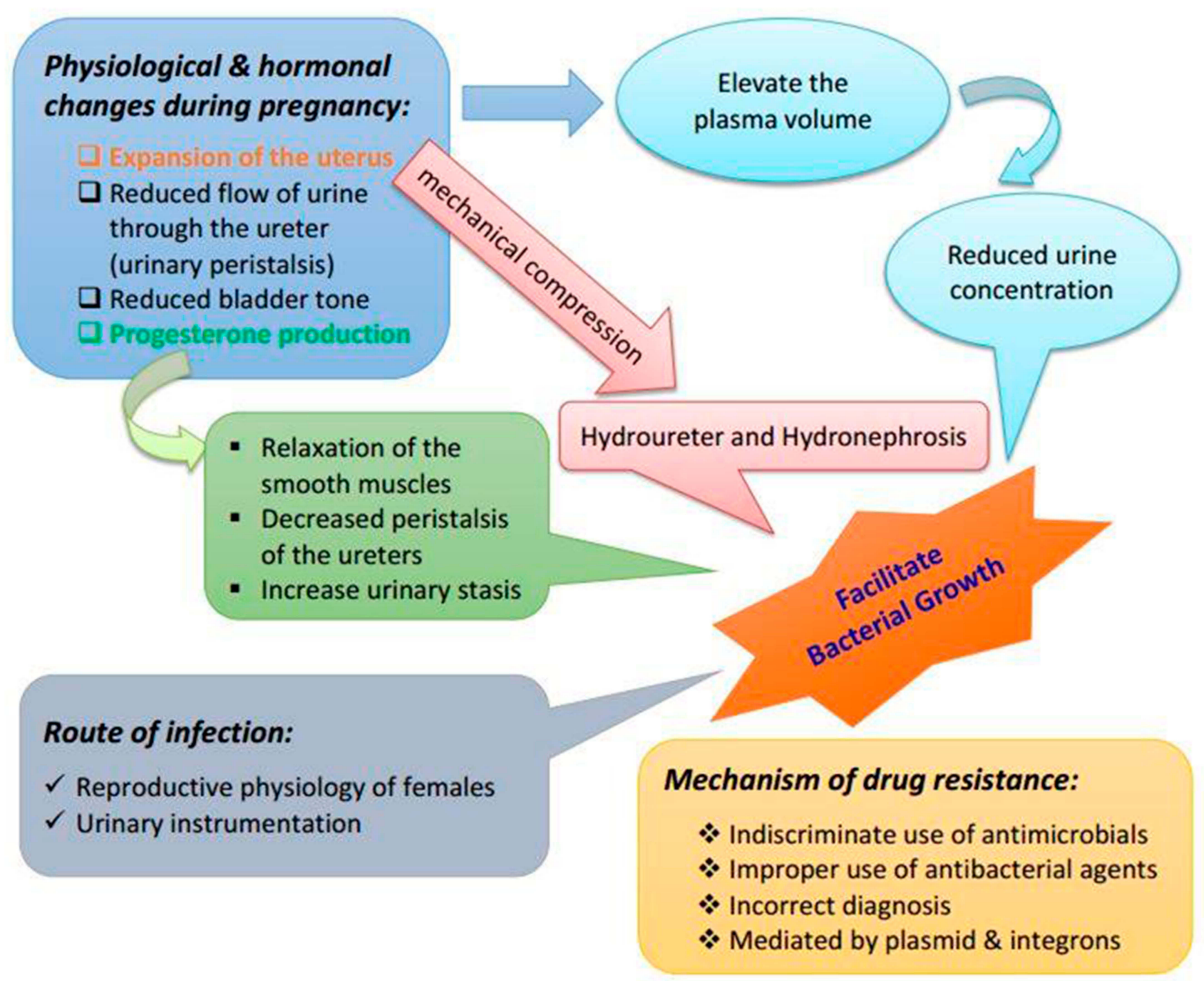

Figure 2 A diagrammatic illustration elucidating the possible risk factors of acquiring UTI and mechanism of bacterial drug resistance among pregnant women.

Asian and fifteen African countries, respectively. Likewise, non-hemolytic Streptococci have been isolated from 27 and $33 \%$ of the studies conducted in eleven Asian and fifteen African countries, respectively. Citrobacter was also reviewed in 18 and $27 \%$ of the studies carried out in eleven Asia and fifteen African countries, respectively (Table 1).

Of the total 24,248 urine sample data collected from the 26 eligible studies published from 2005 to 2016, 3271 (13.5\%) overall prevalence of UTI was reported in developing countries. Among the causative agents 1804 (55.2\%) E. coli bacteria were isolated followed by Klebsiella species (14.6\%). $S$. aureus covered $8.3 \%$ of the isolates. Coagulase negative Staphylococci, Enterococcus and P. mirabilis contributed 5.3, 3.7 and $3.2 \%$ respectively. The review further revealed that less isolated uropathogens including $P$. aeruginosa, Enterobacter, Non-hemolytic streptococci and Citrobacter were contributed $2.8,2.8,1.5$ and $1 \%$ of the isolated UTI causing bacteria (Table 1).

The pooled mean resistance of $E$. coli to ampicillin, nalidixic acid, amoxicillin, gentamicin, Trimethoprim-sulfamethoxazole, Norfloxacin, Nitrofurantoin, Ciprofloxacin and Ceftriaxone was 77.9, 68.7, 57.2, 50.6, 52.8, 36.9, 34.7, 34 and $14.9 \%$ respectively. The pooled mean resistance of $S$. aureus to ampicillin, ciprofloxacin, trimethoprim- sulfamethoxazole and norfloxacin was 63.7, 54.9, 51.3 and $45.8 \%$ respectively. Similarly, the pooled mean resistance of $C N$ staphylococci to trimethoprim-sulfamethoxazole, ampicillin, norfloxacin, gentamicin, nalidixic acid, nitrofurantoin, amoxicillin, ciprofloxacin and ceftriaxone was $68.9,61.8,57.3,46.6,42.8,40.2,39.3,31.4$ and $23.5 \%$, respectively. The pooled mean resistance of Klebsiella spp. to ampicillin, amoxicillin, trimethoprimsulfamethoxazole, nalidixic acid, nitrofurantoin, gentamicin, norfloxacin, ceftriaxone and ciprofloxacin were 70.6, $59.5,54.9,46.8,44.3,36.9,32.3,27.1$ and $25.5 \%$ respectively. The pooled mean resistance of $P$. aeruginosa to trimethoprim-sulfamethoxazole, norfloxacin, nalidixic acid, ampicillin, nitrofurantoin, ceftriaxone, amoxicillin, gentamicin, and ciprofloxacin was 75, 66.6, 54.2, 52, 47.6, $45.9,44.5,42.6$ and $8.3 \%$ respectively. On the other hand, the pooled mean resistance of $P$. mirabilis to ampicillin, trimethoprim-sulfamethoxazole, amoxicillin, nalidixic acid, gentamicin, nitrofurantoin, norfloxacin, ceftriaxone and ciprofloxacin was 76.2, 67.8, 43.9, 41.6, 38.8, 29.7, 18.7, 16.8 and $9.8 \%$ respectively (Table 5) (Figure 3).

Most of the uropathogenic bacteria developed high resistance to Ampicillin. In addition, more than half of isolates developed resistance to Trimethoprim- 
Table 4 Risk Factors Associated with UTI Among Pregnant Women Reviewed from Asia and Africa from 2005 to 2016

\begin{tabular}{|c|c|c|c|}
\hline $\begin{array}{l}\text { First } \\
\text { Author }\end{array}$ & Continent & Significantly Associated with Bacteriuria & Not Significantly Associated with Bacteriuria \\
\hline Derese $^{15}$ & Africa & $\begin{array}{l}\text { Past history of UTI, family monthly income } \leq 500 \text { birr } \\
\text { and } 50 \mathrm{I}-1000 \text { birr, age groups of } 25-34 \text { years, and } \\
\text { educational level }\end{array}$ & $\begin{array}{l}\text { History of catheter, History of antibiotics, Parity, } \\
\text { gestational age }\end{array}$ \\
\hline Jenifer ${ }^{36}$ & Asia & - & $\begin{array}{l}\text { Gestational diabetes, past UTI, multiparity, advanced } \\
\text { maternal age, lower education level, advanced } \\
\text { gestational age and lower socioeconomic status. }\end{array}$ \\
\hline $\operatorname{Labi}^{39}$ & Africa & Being frequently sexually active during pregnancy & $\begin{array}{l}\text { Educational status, parity, gestational age, marital status } \\
\text { and the number of fetuses carried, sexual frequency }\end{array}$ \\
\hline $\operatorname{Sibi}^{19}$ & Asia & $\begin{array}{l}\text { Age group between } 25-34 \text { years, High sexual activities, } \\
\text { recent use of diaphragm with spermicide }\end{array}$ & Gestational age of pregnancy \\
\hline Thapa $^{21}$ & Asia & $\begin{array}{l}\text { Parity, education status, occupation of pregnant women, } \\
\text { times of bathing, history of UTI }\end{array}$ & Age group, pregnancy Trimester, Smoking habit \\
\hline Vaijanathrao ${ }^{3}$ & Asia & - & Gestational diabetic mellitus, Gestational age \\
\hline $\mathrm{Oli}^{22}$ & Africa & Educational level, & Gestational age \\
\hline Alemu $^{14}$ & Africa & History of catheterization and previous history of UTI & $\begin{array}{l}\text { Maternal age, address, parity, gravidity, trimester, } \\
\text { occupation, marital status, education }\end{array}$ \\
\hline $\operatorname{Turpin}^{25}$ & Africa & Gestational age & Parity \\
\hline Hamdan ${ }^{27}$ & Africa & - & Age, gestational age, parity, and history of UTI \\
\hline Mokube ${ }^{28}$ & Africa & - & Gravidity, parity \\
\hline Andabati ${ }^{31}$ & Africa & - & $\begin{array}{l}\text { Education level, Marital status, Smoking, Alcohol, } \\
\text { Gravidity, Antibiotic (oral/injectable) used in the } \\
\text { previous two weeks, gestational age }\end{array}$ \\
\hline Sharifa ${ }^{32}$ & Asia & Age, gravidity & History of previous abortions \\
\hline Okon $^{23}$ & Africa & $\begin{array}{l}\text { Tertiary education, third trimester, multi-gravidity, } \\
\text { multiparity }\end{array}$ & - \\
\hline Manjula $^{20}$ & Asia & Gestational age, parity, age group & - \\
\hline Haider $^{37}$ & Asia & $\begin{array}{l}\text { Illiteracy (Educational status), history of sexual activity, } \\
\text { low socioeconomic (monthly income < Rs. I0,000/ } \\
\text { month) group, past history of UTI and multiparity }\end{array}$ & Age group, haemoglobin level \\
\hline Enayat $^{38}$ & Asia & Hemoglobin level & Age, gravidity, Parity, \\
\hline Thairu ${ }^{24}$ & Africa & $\begin{array}{l}\text { Age group, fever, previous symptoms of UTI, gestational } \\
\text { age, }\end{array}$ & Gravidity \\
\hline Masinde ${ }^{34}$ & Africa & Low socioeconomic status & $\begin{array}{l}\text { Maternal age, parity, gestational age, occupation, marital } \\
\text { status, educational level }\end{array}$ \\
\hline
\end{tabular}

sulfamethoxazole and sensitivity to Ciprofloxacin and Nalidixic acid. The possible reason for such rise in drug resistance might be repeated, inappropriate, and incorrect use of antimicrobial agents in empirical treatment and poor infection control strategies which in turn raise the prevalence of resistant microorganism in the community.

Most of the reviewed studies indicated that past history of UTI, low income and frequent sexual activity during pregnancy had been significantly associated with UTI 


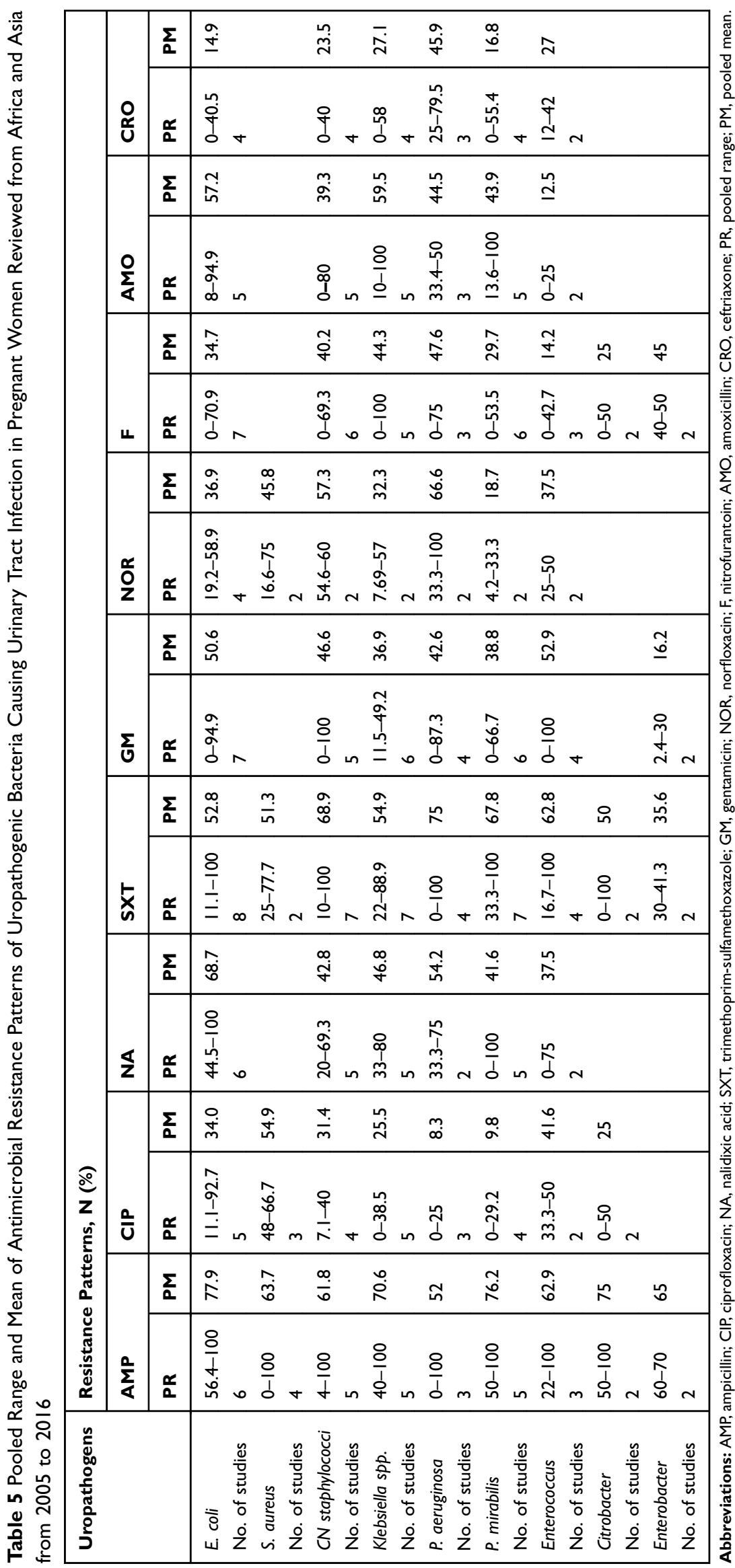




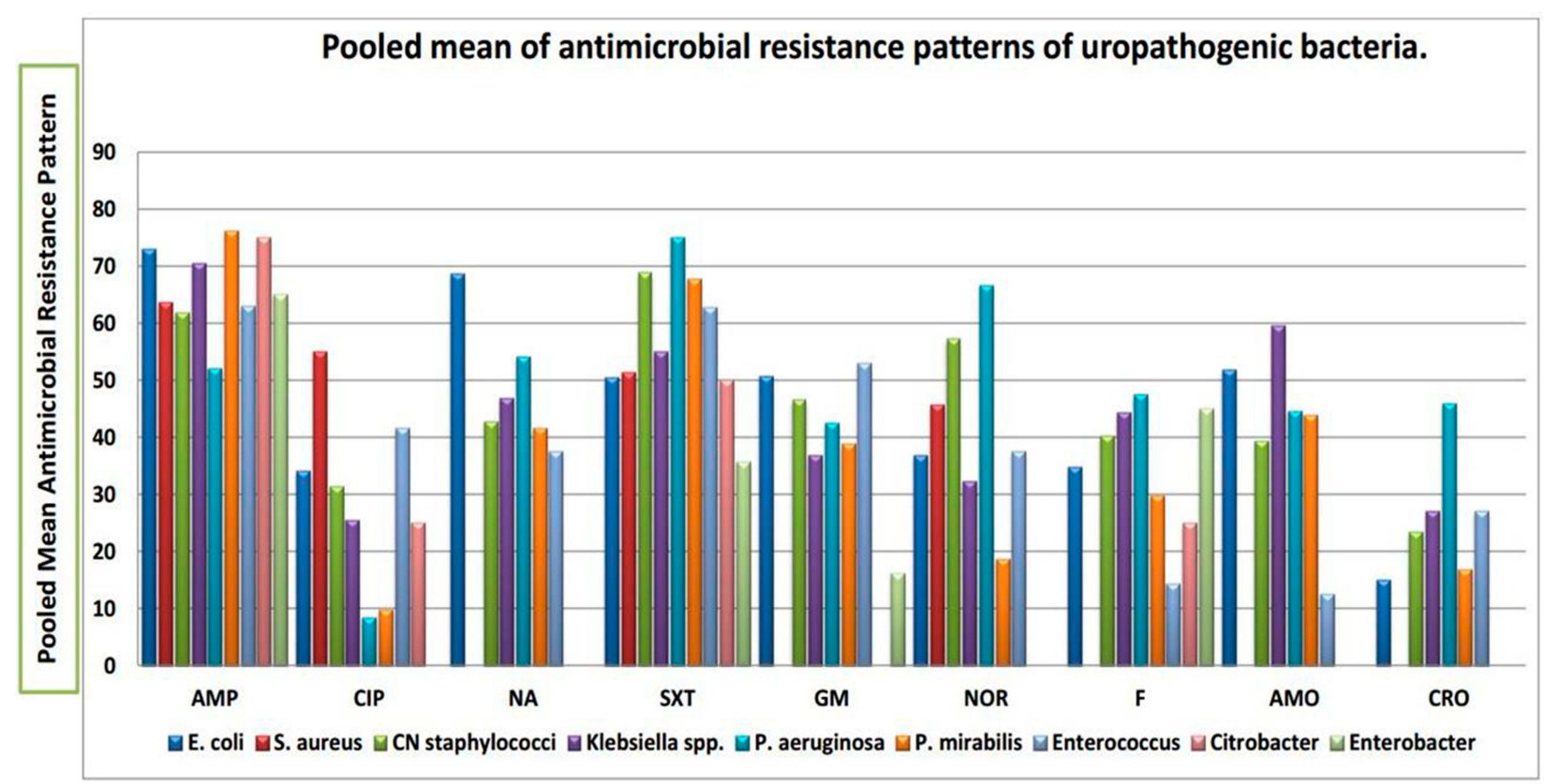

Figure 3 Pooled mean antimicrobial resistance patterns of uropathogenic bacteria among pregnant women in developing countries in Africa and Asia from 2005 to 2016.

among pregnant women. Moreover, nearly half of the reviewed eligible studies have revealed that risk factors including maternal educational level, age, parity, gestational age, gravidity and history of catheterization have been found to be significantly associated with the development of UTI during pregnancy.

\section{Conclusion}

The prevalence of UTI in the selected regions of the two continents is different. A significant prevalence of UTI among pregnant women is mainly observed in Africa and Asia. Uropathogenic bacteria showed resistance to antimicrobial drugs that are regularly used in developing countries. Despite this increased extent, most of the reviewed studies revealed that routine culture and antibiotic susceptibility testing were not being performed as an essential part of antenatal care and the treatment is an empirical basis. This may show the need to incorporate culture and drug susceptibility tests into the routine antenatal care of pregnant women and drug resistance should be monitored. Moreover, as a preventive approach for UTI and emerging antimicrobial drug resistance, instant UTI culture assessment of pregnant women, especially those having possible risk factors such as previous histories of UTI and catheterization etc.; moreover, appropriate prescription and use of antibiotics is necessary.

\section{Ethics and Consent Statement}

As the data were taken from databases of different publishers, ethical approval and consent to participate are not applicable.

\section{Author Contributions}

All authors made substantial contributions to conception and design, acquisition of data, or analysis and interpretation of data; took part in drafting the article or revising it critically for important intellectual content; gave final approval of the version to be published; and agree to be accountable for all aspects of the work.

\section{Authors' Information}

Melaku Ashagrie Belete (MSc, Lecturer in Department of Medical Laboratory Science, College of Medicine and Health Science, Wollo University). Dr. Muthupandian Saravanan $(\mathrm{PhD}$, Associate Professor in Department of Medical Microbiology and Immunology, Mekelle University).

\section{Disclosure}

The authors declare that they have no competing interests.

\section{References}

1. Johansen TE, Botto H, Cek M, Grabe M, Tenke P. Critical review of current definitions of urinary tract infections and proposal of an EAU/ ESIU classification system. Int $J$ Antimicrob Agents. 2011;38 Suppl:64-70. doi:10.1016/j.ijantimicag.2011.09.009 
2. Rosana Y, Ocviyanti D, Putri Akhmad SR. Comparison of microbial pattern causing urinary tract infection in female out- and hospitalized patients in Jakarta. Microbiol Indones. 2016;10(1):30-37. doi:10.5454/ mi.10.1.5

3. Vaijanathrao CY, Nalini YL, Reddy CM. Antibiotic sensitivity pattern of uropathogens: a comparative study between symptomatic and asymptomatic bacteriuria in pregnant women. Int J Curr Microbiol App Sci. 2015;4(6):689-695.

4. Iregbu KC, Nwajiobi-Princewill PI. Urinary tract infections in a tertiary hospital in Abuja, Nigeria. Afr $J$ Clin Exper Microbiol. 2013;14(3):169-173.

5. Vasudevan R. Urinary tract infection: an overview of the infection and the associated risk factors. J Microbiol Exp. 2014;1(2):00008. doi:10.15406/jmen.2014.01.00008

6. Gilbert NM, Macones G. Urinary tract infection as a preventable cause of pregnancy complications: opportunities, challenges, and a global call to action. Global Adv Health Med. 2013;2(5):59-69. doi:10.7453/gahmj.2013.061

7. Rahimkhani M, Khaveri-Daneshvar H, Sharifian R. Asymptomatic bacteriuria and pyuria in pregnancy. Acta Med Iran. 2006;46(5):409-412.

8. Amiri M, Lavasani Z, Norouzirad R, Najibpour R, Mohamadpour M, Nikpoor AR. Prevalence of urinary tract infection among pregnant women and its complications in their newborns during the birth in the hospitals of Dezful City, Iran, 2012 - 2013. Iran Red Crescent Med J. 2015;17(8):e26946. doi:10.5812/ircmj.26946

9. Rizvi M, Khan F, Shukla I, Malik A. Shaheen. rising prevalence of antimicrobial resistance in urinary tract infections during pregnancy: necessity for exploring newer treatment options. J Lab Physicians. 2011;3(2):98-103. doi:10.4103/0974-2727.86842

10. Jain V, Das V, Agarwal A, Pandey A. Asymptomatic bacteriuria \& obstetric outcome following treatment in early versus late pregnancy in north Indian women. Indian J Med Res. 2013;137(4):753-758.

11. Chakupurakal R, Ahmed M, Sobithadevi D, Chinnappan S, Reynolds T. Urinary tract pathogens and resistance pattern. J Clin Pathol. 2010;63::652-654. doi:10.1136/jcp.2009.074617

12. Haque R, Akter ML, Abdus Salam M. Prevalence and susceptibility of uropathogens: a recent report from a teaching hospital in Bangladesh. BMC Res Notes. 2015;8:416.

13. Vardi M, Kochavi T, Denekamp Y, Bitterman H. Risk factors for urinary tract infection caused by Enterobacteriaceae with extendedspectrum beta-lactamase resistance in Patients admitted to internal medicine departments. IMAJ. 2012;14:115-118.

14. Alemu A, Moges F, Shiferaw Y, et al. Bacterial profile and drug susceptibility pattern of urinary tract infection in pregnant women at University of Gondar teaching hospital, in Northwest Ethiopia. BMC Res Notes. 2012;5:197.

15. Derese B, Kedir H, Teklemariam Z, Weldegebreal F, Balakrishnan S. Bacterial profile of urinary tract infection and antimicrobial susceptibility pattern among pregnant women attending at antenatal Clinic in Dil Chora Referral Hospital, Dire Dawa, Eastern Ethiopia. Ther Clin Risk Manag. 2016;12:251-260. doi:10.2147/TCRM.S99831

16. Obirikorang C, Quaye L, Bio FY, Amidu N, Acheampong I, Addo K. Asymptomatic bacteriuria among pregnant women attending antenatal clinic at the University Hospital, Kumasi, Ghana. JMBS. 2012;1(1):38-44.

17. Demilie T, Beyene G, Melaku S, Tsegaye W. Urinary bacterial profile and antibiotic susceptibility pattern among pregnant women in North West Ethiopia. Ethiop J Health Sci. 2012;22:121-128.

18. Kabew G, Abebe T, Miheret A. A retrospective study on prevalence and antimicrobial susceptibility patterns of bacterial isolates from urinary tract infections among pregnant women in Tikur Anbessa Specialized Teaching Hospital Addis Ababa, Ethiopia. Ethiop $J$ Health Dev. 2013;27(2):111-117.

19. Sibi G, Kumari P, Neema K. Antibiotic sensitivity pattern from pregnant women with urinary tract infection in Bangalore, India. Asian Pac J Trop Med. 2014;7(Suppl 1):S116-S120. doi:10.1016/ S1995-7645(14)60216-9
20. Manjula NG, Girish C, Math GC, Patil SA, Gaddad SM, Shivannavar $\mathrm{CT}$. Incidence of urinary tract infections and its aetiological agents among pregnant women in Karnataka Region. Adv Microbiol. 2013;3:473-478. doi:10.4236/aim.2013.36063

21. Thapa R, Lamichhane P, Banjara MR, Acharya GP. Prevalence of extended spectrum beta lactamase producing uropathogens in pregnant women. Asian J Pharm Clin Res. 2015;8(1):207-210.

22. Oli A, Okafor CI, Ibezim EC, Akujiobi CN, Onwunzo MC, Prevalence T. Bacteriology of asymptomatic bacteriuria among antenatal patients in Nnamdi Azikiwe University Teaching Hospital Nnewi; South Eastern Nigeria. Nigerian J of Clin Prac. 2010;13 (4):409-412.

23. Okon KO, Nkwalaku L, Balogun ST, et al. Antimicrobial susceptibility profile of bacterial pathogens isolated from pregnant women with asymptomatic bacteriuria at Tertiary Hospital in Northeastern Nigeria. SLJBR. 2012;4(1):32-42.

24. Thairu Y, Hadijat-Oluseyi KY. Urinary tract infections in symptomatic pregnant women attending university of Abuja Teaching Hospital, Gwagwalada, Nigeria. Jos J Med. 2013;9(1).

25. Turpin CA, Minkah B, Danso KA, Frimpong EH. Asymptomatic bacteriuria in pregnant women attending antenatal clinic at Komfo Anokye Teaching Hospital, Kumasi, Ghana. Ghana Med J. 2007;41(1).

26. Moghadas AJ, Irajian G. Asymptomatic Urinary Tract Infection in Pregnant Women. Iran J Pathol. 2009;4(3):105-108.

27. Hamdan HZ, Ziad AHM, Ali SK, Adam I. Epidemiology of urinary tract infections and antibiotics sensitivity among pregnant women at Khartoum North Hospital. Ann Clin Microbiol Antimicrob. 2011;10:2.

28. Mokube MN, Atashili J, Halle-Ekane GE, Ikomey GM, Ndumbe PM. Bacteriuria amongst pregnant women in the buea health district, cameroon: prevalence, predictors, antibiotic susceptibility patterns and diagnosis. PLoS One. 2013;8(8):e71086. doi:10.1371/journal. pone. 0071086

29. Al-Haddad AM. Urinary tract infection among pregnant women in Al-Mukalla district, Yemen. East Mediterr Health J. 2005;11(3).

30. Lewis DA, Gumede LYE, Hoven LA, et al. Antimicrobial susceptibility of organisms causing community-acquired urinary tract infections among pregnant in Gauteng Province, South Africa. S Afr Med J. 2013;103(6):377-381. doi:10.7196/SAMJ.6722

31. Andabati G, Byamugisha J. Microbial aetiology and sensitivity of asymptomatic bacteriuria among ante-natal mothers in Mulago hospital, Uganda. Afr Health Sci. 2010;10(4):349-352.

32. Sharifa A, Sibiani A. Asymptomatic bacteriuria in pregnant women in Jeddah, Western Region of Saudi Arabia: call for Assessment. Med Sci. 2010;17(1):29-42.

33. Sabrina J, Aboud S, Kasubi M, Maselle SY. Bacterial isolates and drug susceptibility patterns of urinary tract infection among pregnant women at Muhimbili National Hospital in Tanzania. TJHR. 2010;12(4).

34. Masinde A, Gumodoka B, Kilonzo A, Mshana SE. Prevalence of urinary tract infection among pregnant women at Bugando Medical Centre, Mwanza, Tanzania. Tanzania J Health Res. 2009;11(3).

35. Ullah MA, Barman A. Siddique MA and Haque AK. Prevalence of asymptomatic bacteriuria and its consequences in pregnancy in a rural community of Bangladesh. Bangladesh Med Res Counc Bull. 2007;33:60-64. doi:10.3329/bmrcb.v33i2.1206

36. Jennifer P, Cyril R, Piyumi P, Nimesha G, Renuka J. Asymptomatic bacteriuria in pregnancy: prevalence, risk factors and causative organisms. Sri Lankan J of Inf Dis. 2012;1(2):42-46.

37. Haider G, Zehra N, Afroze A, Haider A. Risk factors of urinary tract infection in pregnancy. J Pak Med Assoc. 2010;60:213-216.

38. Enayat K, Fariba F, Bahram N. Asymptomatic bacteriuria among pregnant women referred to outpatient clinics in Sanandaj, Iran. Int Braz J Urol. 2008;34:699-707. doi:10.1590/S1677-5538200800 0600004 
39. Labi AK, Yawson AE, Ganyaglo GY, Newman MJ. Prevalence and associated risk factors of asymptomatic bacteriuria in antenatal clients in a large teaching hospital in Ghana. Ghana Med J. 2015;49(3).
40. Kabew G, Abebe T, Miheret A. A retrospective study on prevalence and antimicrobial susceptibility patterns of bacterial isolates from urinary tract infections among pregnant women in Tikur Anbessa Specialized Teaching Hospital Addis Ababa, Ethiopia. Ethiop. J. Health Dev. 2013;27(2):111-117.

\section{Publish your work in this journal}

Infection and Drug Resistance is an international, peer-reviewed openaccess journal that focuses on the optimal treatment of infection (bacterial, fungal and viral) and the development and institution of preventive strategies to minimize the development and spread of resistance. The journal is specifically concerned with the epidemiology of

Submit your manuscript here: https://www.dovepress.com/infection-and-drug-resistance-journa| antibiotic resistance and the mechanisms of resistance development and diffusion in both hospitals and the community. The manuscript management system is completely online and includes a very quick and fair peerreview system, which is all easy to use. Visit http://www.dovepress.com/ testimonials.php to read real quotes from published authors. 